\title{
SYYSVEHNÄN VALKUAISPITOISUUDESTA
}

\author{
Orvo Ring \\ Kotieläinhoidon tutkimuslaitos, Tikkurila
}

Saapunut 20. 6. 1958.

Viljakasvien jyväsatojen ravinto- ja käyttöarvo riippuu oleellisesti niiden tärkkelys- ja valkuaispitoisuudesta. Tunnettua on, että vehnän valkuaispitoisuus vaikuttaa ratkaisevasti sen käyttöarvoon mylly- ja leipäteollisuudessa. Mitä enemmän vehnän jyvissä on valkuaista, sen paremmin leipoutuvaa jauhoa niistä saadaan. Myös tiedetään, että vehnän jyvien valkuaispitoisuus vaihtelee varsin väljissä rajoissa riippuen lajikkeesta, maan laadusta, happamuudesta, muokkauksesta ja lannoituksesta sekä sääsuhteista kasvuaikana. Vehnän kvaliteettitutkimuksia on Suomessakin suoritettu paljon $(3,4,5,6,7,8,9$ ja 10). Tuoreimpana esimerkkinä maan laadun ja lajikkeen vaikutuksesta mainittakoon, että maatalouden tutkimuskeskuksen kasvinviljelyslaitoksen syksyllä 1955 korjatuissa syysvehnän lajikekokeissa Varma-vehnän valkuaispitoisuus $(\mathrm{N} \times 6.25)$ vaihteli $13.5-15.4 \%$ välillä ja 15 muun lajikkeen vastaavasti $11.7-16.9 \%$. Kaksi vuotta myöhemmin hietasavimaalla kasvaneessa Varmassa oli valkuaista $16.0 \%$ ja 10 muussa lajikkeessa 13.4 $18.3 \%$, ja vastaavasti multavalla karkealla hietamaalla sitä oli Varmassa vain $12.6 \%$ ja 4 muussa lajikkeessa 12.3 - $12.9 \%$ (kuiva-ainetta $85 \%$ ).*

Kotieläinhoidon tutkimuslaitoksen ruokintakokeissa vuosien kuluessa käytettyjen kaurojen ja ohrien rehuanalyysituloksissa kiintyi huomio niiden valkuaispitoisuuden suureen vaihteluun. Kauroissa se on vaihdellut 9.2\%:sta $17.6 \%$ :iin kuivaaineessa ja ohrissa ovat vastaavat luvut olleet 10.5 ja $14.8 \%$. Pyrkiessäni lähemmin selvittämään vaihtelujen syitä valitsin tutkimuskasviksi syysvehnän.

Aineistoa kootessani en lähtenyt suurista jyvämääristä otetuista näytteistä, vaan vehnäyksilöistä, tähkistä ja tähkän eri osissa kasvaneista jyvistä. Varmavehnästä keräsin n. 10 aarin alueelta sieltä täältä valikoimatta 60 tähkää sekä lisäksi 16 kokonaista yksilöä. Edellisen vierestä pieniltä $6 \mathrm{~m}^{2}$ koeruuduilta otin lajikkeesta A, 16 tähkää ja lajikkeesta B, 15 tähkää.

Jyvien painon selville saamiseksi punnittiin kahdeksasta Varma-vehnän yksilöstä, joiden tähkällisten korsien luku vaihteli $2-8$, jokainen jyvä erikseen milligramman tarkkuudella. Nämä punnitustulokset ovat taulukossa 1. Jo yleissilmäys

* Kasvinviljelyslaitoksen kertomukset v. 1955 ja 1957. 
$\begin{array}{lllllllllllllllllllllllll}\text { Yksilö Tähkä Jyviä } & 53 & 52 & 51 & 50 & 49 & 48 & 47 & 46 & 45 & 44 & 43 & 42 & 41 & 40 & 39 & 38 & 37 & 36 & 35 & 34 & 33 & 32\end{array}$

N:o N:o kpl

Individ. Ahre Körner

Nr. Nr. St.

\begin{tabular}{|c|c|c|c|c|c|c|c|c|c|c|c|c|c|c|c|c|c|c|c|c|c|c|c|c|}
\hline \multirow[t]{8}{*}{7} & 1 & 39 & & & & & & & & & & & 1 & & & 1 & 2 & 4 & 2 & 4 & 7 & 4 & 3 & 2 \\
\hline & 2 & 28 & & & & & & & & & & & & & & & & & & & & & & \\
\hline & 3 & 24 & & & & & & & & & & & & & & & & & & & & & & 1 \\
\hline & 4 & 25 & & & & & & & & & & & & & & & & & & & & 1 & 3 & 6 \\
\hline & 5 & 25 & & & & & & & & & & & & & & & & 1 & & & & 2 & 1 & 3 \\
\hline & 6 & 21 & & & & & & & & & & & & & & & & & & & & & & \\
\hline & 7 & 26 & & & & & 1 & & 1 & 2 & & 1 & 4 & 1 & 1 & 1 & 1 & 3 & & 1 & 2 & 1 & & 1 \\
\hline & 8 & 31 & & & & & & & & & & & & & & 2 & 1 & 1 & 1 & 4 & 5 & 3 & 1 & 3 \\
\hline \multirow[t]{4}{*}{10} & 1 & 47 & & & & & & & & & & & & 3 & 2 & & 6 & 4 & 4 & 3 & 4 & 3 & 3 & 4 \\
\hline & 2 & 47 & & & & & & & & & & & & 1 & 2 & & 4 & 5 & 2 & 4 & 3 & 3 & 3 & 1 \\
\hline & 3 & 39 & & & & & & & & & & & & & & 1 & 1 & & & 3 & 1 & 3 & 7 & 4 \\
\hline & 4 & 26 & & & & & & & & & & & & & & 1 & 1 & & 1 & 3 & 1 & 1 & & 2 \\
\hline \multirow[t]{5}{*}{11} & 1 & 33 & & & & & & & & & & & & & 1 & & & & & 1 & & 1 & 3 & 2 \\
\hline & 2 & 48 & & & & & & & & & & & & & & 1 & 2 & 1 & & 3 & 5 & 2 & 5 & 4 \\
\hline & 3 & 35 & & & & & & & & & & & 1 & 2 & & & 1 & 3 & & 1 & 1 & 4 & 6 & 2 \\
\hline & 4 & 34 & & & & & & & & & & & & & & 5 & & & 2 & 1 & 7 & & 4 & 2 \\
\hline & 5 & 32 & & & & & & & & & & & & & & & & & & 2 & 2 & 1 & 4 & 1 \\
\hline \multirow[t]{5}{*}{12} & 1 & 37 & 1 & & 1 & 2 & & & 2 & 2 & & 4 & 3 & 6 & 2 & 1 & 2 & 1 & 1 & 2 & & 2 & 1 & 1 \\
\hline & 2 & 39 & & & & & & 1 & & 1 & 2 & 4 & 4 & 1 & 5 & 1 & 1 & 4 & 1 & 2 & 1 & 1 & 1 & 2 \\
\hline & 3 & 34 & & & & & 2 & 1 & 1 & 1 & & 3 & 2 & 3 & & 1 & 2 & 2 & 5 & 4 & 2 & & & 1 \\
\hline & 4 & 29 & & & & & & & & 1 & 1 & 1 & 1 & 1 & 1 & 1 & 1 & 1 & & 2 & 3 & 3 & 2 & 2 \\
\hline & 5 & 36 & & & & & & & & & & & & & & & & & & & & & & 3 \\
\hline \multirow[t]{4}{*}{13} & 1 & 37 & & & & & & & & & & 1 & 5 & 2 & & 4 & 3 & 2 & 2 & 2 & 3 & 4 & 1 & 1 \\
\hline & 2 & 35 & & & & & & & & & 2 & 1 & 2 & 1 & & 4 & 2 & 2 & 1 & & 1 & & 5 & 2 \\
\hline & 3 & 36 & & & & & & & & & & & & & 1 & & 1 & & 2 & 4 & 6 & 2 & 4 & 1 \\
\hline & 4 & 34 & & & 1 & & & 1 & 1 & 1 & 1 & 2 & 4 & 2 & 3 & 3 & 2 & 2 & 1 & 5 & 1 & & & 2 \\
\hline \multirow[t]{2}{*}{14} & 1 & 39 & & 2 & & 1 & 1 & & & 1 & 3 & 4 & 2 & 4 & 3 & 2 & 2 & & 3 & & 2 & 2 & 2 & \\
\hline & 2 & 37 & & 2 & & 3 & & & 2 & 2 & 2 & & & 2 & 4 & 2 & 1 & 3 & 5 & 1 & 1 & 4 & 1 & 2 \\
\hline \multirow[t]{3}{*}{15} & 1 & 24 & & & & & & & & & & & & 1 & 1 & 1 & 1 & & 1 & & 2 & 3 & 3 & 4 \\
\hline & 2 & 39 & & & & & & & & & 2 & 3 & 1 & 1 & 1 & 4 & 1 & 3 & 2 & 3 & 2 & 1 & 3 & 1 \\
\hline & 3 & 33 & & & & & & & & & 1 & 4 & 1 & & & 1 & 2 & 4 & 1 & 2 & 1 & 2 & 4 & 2 \\
\hline \multirow[t]{5}{*}{16} & 1 & 33 & & & & & & 1 & & & 1 & & 1 & 3 & 1 & 6 & 2 & 3 & 2 & 1 & 2 & 1 & 1 & 1 \\
\hline & 2 & 39 & & & 1 & & & 3 & 2 & 2 & 1 & 3 & 4 & & 4 & 2 & 4 & & 4 & 2 & 1 & 1 & & 3 \\
\hline & 3 & 30 & & & & & 1 & & 1 & 2 & & 1 & 3 & 1 & 2 & 1 & & 1 & & 4 & 1 & & 2 & 1 \\
\hline & 4 & 30 & & & & & & & & 2 & 1 & 6 & 1 & 2 & 3 & & 3 & 2 & 2 & 1 & & 1 & & 1 \\
\hline & 5 & 34 & & & & & & & 1 & 2 & 1 & 3 & & 2 & 2 & 2 & 1 & 2 & 2 & 6 & 1 & 1 & 2 & \\
\hline
\end{tabular}
Insges. 
Tabelle 1. Verteilung der Körner aut mg-Gewichtskiassen, St.

$\begin{array}{lllllllllllllllllllllllll}31 & 30 & 29 & 28 & 27 & 26 & 25 & 24 & 23 & 22 & 21 & 20 & 19 & 18 & 17 & 16 & 15 & 14 & 13 & 12 & 11 & 10 & 9 & \text { Jyvän- Raaka- }\end{array}$ paino prot \% kskm. Rohprot. mg \%

Korn-

gewicht

durch-

schn.

$m g$.

$\begin{array}{llllllll}1 & 2 & 1 & 1 & 1 & 1 & 1 & 1\end{array}$

$33.2 \quad 17.1$

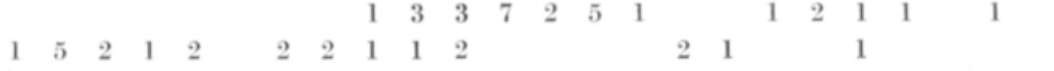

$18.3 \quad 18.5$

$\begin{array}{llllllll}1 & 5 & 3 & 1 & 1 & 1 & 2 & 1\end{array}$

$\begin{array}{llllllllllllllll}2 & 4 & 1 & 1 & 1 & 1 & 1 & 1 & 2 & & & 3 & 1\end{array}$

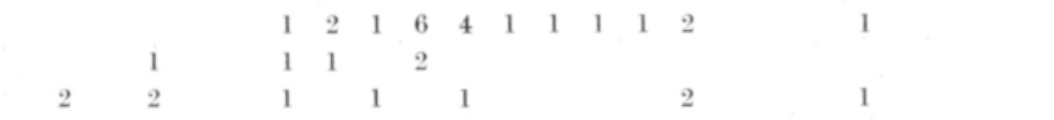

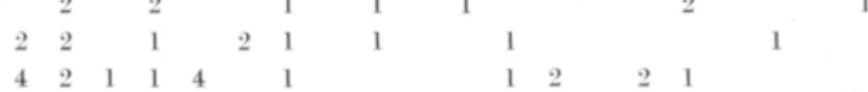

$\begin{array}{llllllllllll}4 & 2 & 1 & 1 & 4 & & 1 & 1 & 2 & & 2 & 1 \\ 5 & 5 & 1 & 2 & 2 & 1 & & 1 & & 1 & & 1\end{array}$

$\begin{array}{llllllllllll}1 & 3 & 1 & 3 & 1 & 1 & 1 & 2 & 2 & 1\end{array}$

$\begin{array}{lllllllllllllllll}7 & 4 & 2 & 3 & 3 & 2 & 1 & 1 & & 1 & & & 1 & & & & \\ 4 & 2 & 2 & 2 & 1 & 2 & & 3 & 1 & 3 & 1 & 1 & 1 & & & 1 & 1\end{array}$

$\begin{array}{llllllllll}2 & 4 & 1 & 1 & 2 & 1 & 1 & & 1 & 1\end{array}$

$\begin{array}{lllllll}2 & 3 & 2 & 1 & 2 & 1 & 2\end{array}$

$\begin{array}{lllllllllll}2 & 3 & 6 & 4 & 2 & 1 & & 2 & 1 & 1\end{array}$

$\begin{array}{lllllll}1 & 1 & & & 1 & & \\ 2 & & 1 & 2 & & 1 & 1 \\ 1 & & & 2 & & & 1\end{array}$

$25.0 \quad 15.7$

$28.6 \quad 16.5$

$28.2 \quad 16.6$

$20.7 \quad 18.5$

$37.6 \quad 18.4$

$31.4 \quad 14.5$

$34.2 \quad 14.9$

$32.3 \quad 14.6$

$31.0 \quad 14.1$

$29.8 \quad 14.7$

$29.6 \quad 15.1$

$29.8 \quad 15.5$

$32.0 \quad 14.2$

$32.1 \quad 14.8$

$27.9 \quad 14.9$

$40.9 \quad 16.2$

$38.0 \quad 14.9$

$38.6 \quad 14.7$

$\begin{array}{llllllll}1 & 3 & 1 & 2 & 1 & 34.1 & 15.2\end{array}$

$\begin{array}{lllllllllllllllllll}3 & 3 & 4 & 2 & 3 & 3 & 1 & 2 & 1 & 3 & 2 & 2 & 1 & 1 & 2 & 25.6 & 14.4\end{array}$

$\begin{array}{rrrrrrrrr}2 & 1 & 1 & 1 & 1 & 1 & 36.1 & 16.1\end{array}$

$\begin{array}{llllllll}2 & 2 & 1 & 1 & 2 & 2 & 1 & 1\end{array}$

$34.4 \quad 15.3$

$\begin{array}{llllll}5 & 2 & 3 & 2 & 2 & 1\end{array}$

$32.3 \quad 15.3$

2

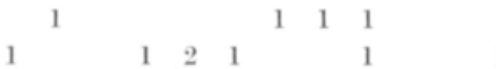

$39.8 \quad 16.7$

$39.4 \quad 18.1$

$40.7 \quad 18.1$

$32.7 \quad 16.7$

$\begin{array}{llllllllll}1 & 2 & 1 & 2 & 1 & 1 & 1 & 1 & 1 \\ 2 & 3 & 1 & 1 & & 1 & & & \end{array}$

$34.6 \quad 15.6$

$35.8 \quad 17.1$

$36.9 \quad 14.8$

$\begin{array}{rrrrr}1 & 1 & 36.9 & 40.5 & 14.7\end{array}$

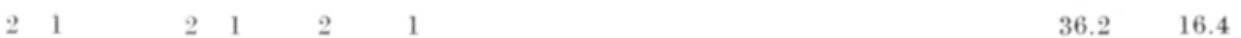

$\begin{array}{lllllrr}1 & 1 & 1 & 1 & 1 & 38.7 & 14.8\end{array}$

$\begin{array}{llllllll}1 & 1 & 1 & 1 & 2 & 37.1 & 14.4\end{array}$

$\begin{array}{llllllllllllllllllllllll}61 & 62 & 32 & 33 & 38 & 23 & 24 & 26 & 17 & 24 & 20 & 22 & 10 & 12 & 7 & 16 & 4 & 3 & 3 & 5 & 1 & & 1 & 33.5\end{array}$ 
taulukkoon osoittaa, että hajonta on suuri yksityisissä tähkissä, yksilöissä ja koko aineistossa. Luvuista nähdään, että saman kasvin eri tähkissä jyvien luku vaihtelee melkoisesti, puhumattakaan eri yksilöiden välisistä hyvinkin suurista eroista. Esim. yksilössä 7, jossa oli 8 tähkää, keskimääräinen jyvien paino vaihteli $18.3-37.6$ mg:aan. Monihaaraisissa yksilöissä on eri korsilla ja tähkillä erilaiset kehittymis-

Taulukko 2. Jyvien keskimääräiset painot ja valkuaispitoisuudet tähkän eri osissa.

Tabelle 2. Durchschnittliche Gewichte und Proteingehalt der Körner in verschiedenen Teilen der Ähre.

\begin{tabular}{|c|c|c|c|c|c|c|c|c|c|c|}
\hline & \multirow[b]{2}{*}{$\begin{array}{c}\text { Tähkän } \\
\text { osa } \\
\text { Teii der } \\
\text { Ahre }\end{array}$} & \multicolumn{2}{|c|}{ Varma } & \multirow[b]{2}{*}{$\begin{array}{c}\text { Val- } \\
\text { kuaista } \\
\% \\
\text { Protein }\end{array}$} & \multicolumn{3}{|c|}{$\begin{array}{c}\text { Lajike A } \\
\text { Sorte } A\end{array}$} & \multicolumn{3}{|c|}{$\begin{array}{l}\text { Lajike B } \\
\text { Sorte B }\end{array}$} \\
\hline Tähkä & & $\begin{array}{c}\text { Jyviä } \\
\text { kpl. } \\
\\
\text { Körner } \\
\text { St. }\end{array}$ & $\begin{array}{l}\text { Jyvän- } \\
\text { paino } \\
\text { keskm. } \\
\text { mg. } \\
\text { Korn- } \\
\text { gewicht } \\
\text { durch- } \\
\text { schn } \\
\text { mg. }\end{array}$ & & $\begin{array}{c}\text { Jyviä } \\
\text { kpl. } \\
\text { Körner } \\
\text { St. }\end{array}$ & $\begin{array}{l}\text { Jyvän } \\
\text { paino } \\
\text { kskm. } \\
\text { mg. } \\
\text { Korn- } \\
\text { gewicht } \\
\text { durch- } \\
\text { schn. } \\
\text { mg. }\end{array}$ & $\begin{array}{c}\text { Val- } \\
\text { kuaista } \\
\% \\
\text { Protein } \\
\%\end{array}$ & $\begin{array}{c}\text { Jyviä } \\
\text { kpl. } \\
\\
\text { Körner } \\
\text { St. }\end{array}$ & $\begin{array}{c}\text { Jyvän- } \\
\text { paino } \\
\text { kskm. } \\
\text { mg. } \\
\text { Korn- } \\
\text { gewicht } \\
\text { durch- } \\
\text { schn. } \\
\text { mg. }\end{array}$ & $\begin{array}{c}\text { Val- } \\
\text { kuaista } \\
\% \\
\text { Protein } \\
\%\end{array}$ \\
\hline \multirow[t]{2}{*}{1} & $\begin{array}{l}\text { ylä } \\
\text { oberer }\end{array}$ & 15 & 29.2 & 16.2 & 9 & 37.5 & 16.7 & 16 & 34.5 & 12.4 \\
\hline & $\begin{array}{l}\text { keski } \\
\text { mittlerer } \\
\text { ala } \\
\text { unterer }\end{array}$ & 14 & 32.2 & 17.0 & 10 & 47.8 & 18.2 & 16 & 42.0 & 13.3 \\
\hline \multirow[t]{3}{*}{2} & $\begin{array}{l}\text { ylä } \\
\text { oberer }\end{array}$ & 12 & 38.3 & 17.2 & 11 & 34.6 & 14.6 & 13 & 34.2 & 12.2 \\
\hline & $\begin{array}{l}\text { keski } \\
\text { mittlerer }\end{array}$ & 12 & 43.9 & 18.9 & 11 & 37.8 & 15.3 & 14 & 47.8 & 12.5 \\
\hline & $\begin{array}{l}\text { ala } \\
\text { unterer }\end{array}$ & 12 & 41.9 & 18.4 & 11 & 37.6 & 15.2 & 14 & 43.7 & 12.3 \\
\hline \multirow[t]{3}{*}{3} & $\begin{array}{l}\text { ylä } \\
\text { oberer }\end{array}$ & 17 & 34.5 & 13.5 & 8 & 33.3 & 15.8 & 14 & 38.0 & 13.7 \\
\hline & $\begin{array}{l}\text { keski } \\
\text { mittlerer }\end{array}$ & 17 & 40.7 & 13.9 & 8 & 43.3 & 17.9 & 15 & 45.4 & 14.4 \\
\hline & $\begin{array}{l}\text { ala } \\
\text { unterer }\end{array}$ & 17 & 36.5 & 13.5 & 9 & 40.1 & 17.9 & 15 & 41.3 & 14.0 \\
\hline \multirow[t]{3}{*}{4} & $\begin{array}{l}\text { ylä } \\
\text { oberer }\end{array}$ & 15 & 28.8 & 9.6 & 12 & 34.7 & 14.8 & 17 & 35.6 & 13.1 \\
\hline & $\begin{array}{l}\text { keski } \\
\text { mittlerer }\end{array}$ & 15 & 36.5 & 10.4 & 12 & 41.1 & 16.1 & 17 & 43.4 & 13.6 \\
\hline & $\begin{array}{l}\text { ala } \\
\text { un'erer }\end{array}$ & 15 & 35.2 & 10.3 & 12 & 37.6 & 15.8 & 17 & 41.5 & 13.6 \\
\hline $\begin{array}{l}\text { Keski- } \\
\text { määrin }\end{array}$ & $\begin{array}{l}\text { ylä } \\
\text { oberer }\end{array}$ & & 32.5 & 14.1 & & 35.0 & 15.4 & & 35.6 & 12.9 \\
\hline \multirow[t]{2}{*}{$\begin{array}{l}\text { Durch- } \\
\text { schn. }\end{array}$} & $\begin{array}{l}\text { keski } \\
\text { mittlerer }\end{array}$ & & 39.2 & 14.9 & & 42.3 & 16.9 & & 44.5 & 13.4 \\
\hline & $\begin{array}{l}\text { ala } \\
\text { unterer }\end{array}$ & & 36.2 & 14.7 & & 38.9 & 16.7 & & 41.8 & 13.3 \\
\hline
\end{tabular}


mahdollisuudet, niinpä tähkissä 2 ja 6 , joiden korret olivat muita huomattavasti lyhyemmät ja hennommat, oli hyvin heikosti kehittyneitä ja kevyitä jyviä, kun sen sijaan tähkän 7 korsi oli pisin ja tukevin ja sen jyvät olivat hyvin kehittyneitä. Koko aineiston keskimääräinen jyvänpaino oli $33.5 \mathrm{mg}$, mikä on alhainen normaaliin verrattuna (n. $40 \mathrm{mg}$ ). Tässä yhteydessä mainittakoon, että eräät kasvitaudit ja tuhohyönteiset aiheuttavat vehnissä kahutähkäisyyttä, jolloin jyvät jäävät kooltaan normaalia pienemmiksi ja kurttupintaisiksi (1 ja 2).

Tutkittaessa tähkän eri osissa kasvaneita jyviä irroitettiin kaikkien kolmen lajikkeen 4 tähkän jyvät yksitellen yläpäästä alkaen ja jaettiin irroittamisjärjestyksessä lukumäärän mukaan kolmeen yhtäsuureen osaan, ylä-, keski- ja alaosaan. Nämä jyväerät punnittiin erikseen ja niistä tehtiin typenmääritykset. Taulukosta 2, jossa tulokset on esitetty, nähdään, että tähkän keskimmäiset jyvät olivat säännöllisesti raskaimmat ja yläosassa olevat keveimmät. Samassa tähkässä on suurin ero suurimman ja pienimmän painon välillä $13.6 \mathrm{mg}$, eli keskimmäiset jyvät painavat n. $40 \%$ enemmän kuin yläosan jyvät (lajike B, tähkä 2).

Miten suuret sitten olivat valkuaispitoisuuden vaihtelut? Taulukosta 2 ilmenee, että tähkän latvajyvät sisälsivät vähiten valkuaista, ainoastaan Varman tähkässä 3, oli sitä ylä- ja alaosassa yhtä paljon. Keskimmäisissä jyvissä oli valkuaista yleensä eniten, paitsi yhdessä tapauksessa oli korkein pitoisuus alaosassa sekä 3 tapauksessa keski- ja alaosassa sama. Asia näkyy selvimmin lajikkeiden keskiarvoista, jotka on laskettu kunkin neljän tähkän vastaavien osien jyvien yhteispainosta ja valkuaismäärästä, eikä taulukossa olevien mg- ja prosenttilukujen perusteella. Ero suurimman ja pienimmän pitoisuuden välillä samassa tähkässä on $2.1 \%$ yksikköä, siis valkuaispitoisuus on keskimmäisissä jyvissä $13 \%$ suurempi kuin yläosan jyvissä (lajike A, tähkä 3).

Taulukossa 3 on esitetty tähkien jakautuminen jyvien valkuaispitoisuuden mukaan eri luokkiin. Luvuista nähdään, että samassa lajikkeessa valkuaispitoisuus vaihteli samoin kuin jyvien painotkin, varsin väljissä rajoissa ollen Varmassa 9.1$18.5 \%$, lajikkeessa A 14.5-18.2 \% ja lajikkeessa B 11.9-17.4 \%. Tässä aineistossa oli Varman tähkistä kaksikolmasosaa 14 ja 17 valkuaisprosentin välillä.

Taulukossa 1 on esitettynä paitsi jyvien painoja myös vehnäyksilöiden eri tähkien valkuaispitoisuudet. Yksilössä 7, joka oli kahdeksankortinen, vaihtelut ovat

Taulukko 3. Tähkien jakautuminen valkuaispitoisuuden mukaan, kpl.

Tabelle 3. Verteilung der Ahren nach dem Proteingehalt, St.

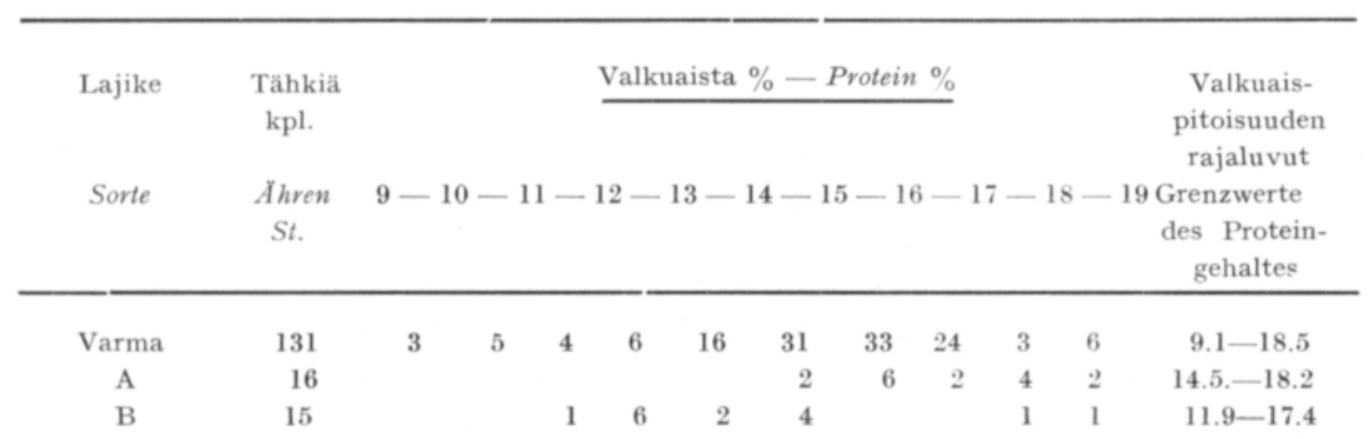


Taulukko 4. Keskimääräisen jyvänpainon ja valkuaispitoisuuden vertailu.

Tabelle 4. Vergleich von durchschnittlichen Korngewicht und Proteingehalt.

\begin{tabular}{|c|c|c|c|c|c|c|c|c|}
\hline & & Varma & & & $\begin{array}{c}\text { Lajike A } \\
\text { Sorte } A\end{array}$ & & & $\begin{array}{c}\text { Lajike B } \\
\text { Sorte } B\end{array}$ \\
\hline $\begin{array}{l}\text { Tähkien } \\
\text { kskm. } \\
\text { jyvän- } \\
\text { paino } \\
\text { mg }\end{array}$ & $\begin{array}{c}\text { Tähkiä } \\
\text { kpl. }\end{array}$ & $\begin{array}{c}\text { Val- } \\
\text { kuaista } \\
\%\end{array}$ & kskm. & $\begin{array}{c}\text { Tähkiâ } \\
\text { kpl. }\end{array}$ & $\begin{array}{c}\text { Val- } \\
\text { kuaista } \\
\%\end{array}$ & kskm. & $\begin{array}{c}\text { Tähkiä } \\
\text { kpl. }\end{array}$ & $\begin{array}{c}\text { Val- } \\
\text { kuaista }\end{array}$ \\
\hline $\begin{array}{c}\text { Durch- } \\
\text { schn. } \\
\text { Gewicht } \\
\text { der Ahren } \\
\text { mg. }\end{array}$ & $\begin{array}{c}\text { Ahren } \\
\text { St. }\end{array}$ & $\begin{array}{c}\text { Protein } \\
\%\end{array}$ & $\begin{array}{c}\text { durch- } \\
\text { schn. }\end{array}$ & $\begin{array}{c}\text { Ahren } \\
\text { St. }\end{array}$ & $\begin{array}{c}\text { Protein } \\
\%\end{array}$ & $\begin{array}{l}\text { durch- } \\
\text { schn. }\end{array}$ & $\begin{array}{c}\text { Ahren } \\
\text { St. }\end{array}$ & $\begin{array}{c}\text { Protein } \\
\%\end{array}$ \\
\hline
\end{tabular}

\begin{tabular}{|c|c|c|c|c|c|c|c|c|}
\hline $17-18$ & 2 & $17.2-18.5$ & & & & & & \\
\hline $21-29$ & 10 & $14.4-18.5$ & & 4 & $14.5-17.2$ & & & \\
\hline 30 & 4 & $14 . \mathrm{C}-16.1$ & 14.6 & 2 & $17.5-18.1$ & & 1 & 11.9 \\
\hline 31 & 5 & $9.1-16.4$ & 13.8 & & & & 1 & 12.9 \\
\hline 32 & 10 & $14.1-16.8$ & 15.2 & 3 & $16.0-18.2$ & 16.9 & & \\
\hline 33 & 9 & $9.9-16.7$ & 14.9 & 1 & 15.1 & & 2 & $12.8-14.6$ \\
\hline 34 & 13 & $11.8-16.9$ & 14.5 & 1 & 15.9 & & & \\
\hline 35 & 12 & $11.7-17.1$ & 14.2 & & & & & \\
\hline 36 & 7 & $9.4-16.4$ & 13.9 & 1 & 15.0 & & & \\
\hline 37 & 10 & $11.6-18.4$ & 14.6 & 2 & $15.6-16.9$ & & 1 & 16.1 \\
\hline 38 & 12 & $12.8-15.9$ & 14.4 & 1 & 17.3 & & & \\
\hline 39 & 8 & $10.8-18.1$ & 14.7 & & & & 2 & $12.3-13.0$ \\
\hline 40 & 5 & $14.0-18.1$ & 15.7 & & & & 1 & 13.5 \\
\hline 41 & 8 & $10.3-18.2$ & 15.2 & & & & 1 & 14.0 \\
\hline 42 & 5 & $11.4-15.3$ & 13.9 & 1 & 17.8 & & 2 & $12.3-12.3$ \\
\hline 43 & 4 & $15.0-16.6$ & 15.8 & & & & & \\
\hline 44 & - & & & & & & & \\
\hline 45 & 4 & $10.9-16.4$ & 14.4 & & & & & \\
\hline 46 & 2 & $13.3-15.4$ & 14.4 & & & & 1 & 13.5 \\
\hline 47 & 1 & 14.6 & & & & & 1 & 14.9 \\
\hline 48 & & & & & & & 1 & 17.4 \\
\hline 53 & & & & & & & 1 & 14.7 \\
\hline $\begin{array}{l}\text { Yhteensä } \\
\text { Inges. }\end{array}$ & 131 & $9.1-18.5$ & & 16 & $14.5-18.2$ & & 15 & $11.9-17.4$ \\
\hline
\end{tabular}

suurimmat, rajatapausten ollessa 14.5 ja $18.5 \%$. Muissa yksilöissä vaihtelut ovat pienempiä ja yksilössä 14, jossa oli vain 2 tähkällistä kortta, oli molemmissa tähkissä sama valkuaispitoisuus.

Kun tähkän yläosan jyvät olivat yleensä pienimmät ja sisälsivät vähiten valkuaista ja toiselta puolen keskimmäiset jyvät olivat raskaimmat ja valkuaispitoisimmat (taulukko 2), herää kysymys, onko tähkän keskimääräisen jyvänpainon ja valkuaispitoisuuden välillä vuorosuhdetta? Kysymyksen valaisemiseksi on taulukossa 4 tähkät järjestetty niiden nousevan keskimääräisen jyvänpainon mukaan 
ja kunkin painoluokan kohdalle on merkitty ko. tähkän valkuaispitoisuus, tai jos tähkiä on useampia, raja- ja keskiarvot. Varma-vehnän lukujen perusteella ei kysymykseen voida vastata puoleen eikä toiseen, koska pieniä ja suuria pitoisuuksia esiintyy hajanaisesti siellä täällä ja r-arvo $=-0.154 \pm 0.0853$. Lajikkeissa $\mathrm{A}$ ja $\mathrm{B}$ on johtopäätösten teko vieläkin vaikeampaa aineiston pienuuden vuoksi.

Edellisestä on selvinnyt, että saman vehnälajikkeen jyvien valkuaispitoisuudet ja painot vaihtelevat hyvinkin paljon. Pitämällä mielessä, että tutkitut näytteet on otettu varsin suppealta alueelta, kasvoivathan kaikki lajikkeet aivan vierekkäin, ei näytä uskottavalta, että maan laatu, happamuus, muokkaus ja lannoitus sekä valo- ja sääsuhteet aiheuttivat näissä tapauksissa vehnän epätasaisuuden, vaan syitä on haettava muualta. Vehnälajikkeet ovat voineet vuosien mittaan sekaantua niin, että niistä nyt löytyy ominaisuuksiltaan erilaisia yksilöitä. Mutta voihan olla mahdollista, että kyseessä on myös perinnöntekijät. Tämä alustava tutkimus ei anna varmistusta tälle käsitykselle, mutta myöhemmin suoritettavat risteytykset ja linjojen vertailut tuonevat selvityksen kysymykseen.

Kuten jo alussa mainitsin on valkuaispitoisuuden vaihtelua tavattu muissakin viljakasveissa, esim. kaurassa ja ohrassa. Jos niistä voitaisiin valita korkeampiprosenttisia yksilöitä, joiden jälkeläisten valkuaispitoisuus olisi pysyvä ominaisuus, saataisiin jo huomattavia valkuaissadonlisäyksiä, puhumattakaan siitä, että täten saatujen linjojen valkuaispitoisuutta voitaisiin vielä pysyvästi korottaa prosenttiyksiköllä tai kahdella. Mitä merkitsisi myllyteollisuudelle jos vehnän valkuaispitoisuus nousisi lähemmäksi $20 \%(\mathrm{~N} \times 6.25)$. Meillä ei ole viljakasvien jalostustyössä käytetty hyväksi kemiallisia tutkimusmenetelmiä analysoimalla kasviyksilöitä, vaan on määritetty suurista kasvustoista saatujen jyväsatojen keskimääräisiä koostumuksia ja niiden perusteella on päätelty eri lajikkeiden ominaisuuksia.

\section{$P$ ä $\operatorname{tel} m a ̈ t$}

Saman vehnälajikkeen eri yksilöiden ja samankin yksilön eri tähkien sekä eri tähkän osista kasvaneiden jyvien valkuaispitoisuudet ja painot vaihtelevat hyvin paljon.

Tämän aineiston perusteella ei näytä olevan vuorosuhdetta keskimääräisen jyvänpainon ja valkuaispitoisuuden välillä.

\section{KIRJALLISUUTTA}

(1) HÁRDH, J. E. 1953. Kevätvehnän kahutähkäisyydestä sekä sen syistä Suomessa. Referate: On the shrivelheads of spring wheat and their causes in Finland. Valt. maat.koet. julk. 140: 1-152.

(2) Pesola, V. A. 1927. Kevätvehnän keltaruosteenkestävyydestä. Abstract: On the resistance of spring wheat to yellow rust. Ibid. 8: 1-162, 1-22.

(3) —— \& Otтеrströм, B. 1935. Bidrag till kännedom om vetets bakningsförmåga i Finland. Beretning fra N.J. F.s Kongres i Kobenhavn, Juli 1935. Fortryk. Sektion III. Nr. 4. 1 - 14.

(4) $\rightarrow$ \& VEIJolA, T. 1954. Vehnän kvaliteettijalostuksesta ja sen tuloksista Suomessa. Summary: On breeding for quality of wheat in Finland. Maat. tiet. aikak. 26: 178-194. 
(5) Tomula, E. S. 1928. Kotimaisen viljan laatua koskevia tutkimuksia II. Referat: Untersuchungen über die Beschaffenheit des einheimischen Getreides. Valt. maat.koetoim. julk. 20: 1-105.

(6) - 1932. Kotimaisen viljan laatua koskevia tutkimuksia V. Referat: Uber die Verbesserung der Backfähigkeit des einheimischen Weizens durch einige Chemikalien. Ibid. 47: 1-44.

(7) $\rightarrow$ 1933. Kotimaisen viljan laatua koskevia tutkimuksia VI. Uber die Backfähigkeit einiger in Finnland angebauten Winter- und Sommerweizensorten. Ibid. 52: 1-145.

(8) Vefjola, T. 1948. Vehnän valkuaispitoisuudesta ja siihen vaikuttavista tekijöistä. Maatalous ja koetoiminta III: $120-135$.

(9) Veijola, T. \& Keränen, A. J. A. 1951. Kasvukosteuden, erityisesti sadetuksen vaikutuksesta vehnån laatuun. Maatalous, 44: 249-253.

(10) $\longrightarrow$ 1956. Eräiden Suomessa viljeltävien vehnälajikkeiden laatuvertailua. Ibid .49: 250—252.

R E F E R A T:

\title{
UBER DEN PROTEINGEHALT VON WINTERWEIZEN
}

\author{
Orvo Ring
}

Zentrale für Landwirtschaftliche Forschung, Abteilung für Haustierhaltung, Tikkurila.

Bei Untersuchung der Schwankungen des Proteingehaltes in Weizenkörnern sind als Material Weizenindividuen, einzelne Ähren und in den verschiedenen Ährenteilen gewachsene Körner benutzt worden. In Tabelle 1 ist die Verteilung aller Körner von acht Weizenindividuen auf mg-Klassen dargestellt. Die Streuung ist recht gross. Die Körner von vier Ähren dreier Sorten wurden, ausgehend vom oberen Ende, einzeln herausgelöst und in der Entnahmereihenfolge nach der Anzahl in drei gleich grosse Teile geschieden, einen oberen, einen mittleren und einen unteren Teil. Diese Kornmengen wurden gewogen und Stickstoffbestimmungen über sie gemacht. Aus Tabelle 2 ist zu ersehen, dass die mittleren Körner regelmässig am schwersten und die oberen am leichtesten waren. Die Körner des oberen Teiles enthielten am wenigsten Protein und die des mittleren Teiles am meisten, nur lag in einem Falle der höchste Gehalt im unteren Teile, und in drei Fällen war er im mittleren und unteren Teil gleich. Der Sachverhalt ist deutlicher aus den für die Sorten angegebenen Mittelwerten zu ersehen, die aus dem Gesamtgewicht und der Rohproteinmenge der Körner des entsprechenden Teiles der vier Ähren und nicht auf Grund der in der Tabelle angeführten mg- und Prozentzahlen berechnet worden sind. Der Unterschied zwischen dem grössten und dem kleinsten Proteingehalt beträgt $2.1 \%$ - Einheiten. Aus Tabelle 3 ist zu ersehen, wie sich die Ähren auf die verschiedenen Proteingehaltklassen verteilen. Bei einer und derselben Sorte wechselt der Proteingehalt in recht weiten Grenzen. Beim Varma-Weizen macht er 9.1-18.5\% aus, bei der Sorte A 14.5-18.2 und bei der Sorte B 11.9-17.4\%.

Besteht zwischen den durchschnittlichen Korngewichten und dem Protein gehalt eine Korrelation? Zur Beleuchtung der Frage sind in Tabelle 4 die Ähren nach ihren steigenden durchschnittlichen Korngewichten angeordnet, und bei jeder Gewichtsklasse ist der Proteingehalt der betreffenden Ähre oder, wenn es sich um mehrere Ähren handelt, die Grenz- und Mittelwerte angegeben. Da kleine und grosse Gehalte hier und da verstreut auftreten und $\mathrm{r}=-0.154 \pm 0.0853$ ist, kann die Frage nicht bejahend beantwortet werden.

Da das Material aus einem recht kleinen Gebiet eingebracht worden ist, dis Varma-Weizenproben von etwa $1000 \mathrm{~m}^{2}$ und die übrigen Sorten von daneben gelegenen $6 \mathrm{~m}^{2}$ grossen Probeflächen, ist nicht anzunehmen, dass Beschaffenheit, Azidität, Bearbeitung und Düngung des Bodens und Witterungsverhältnisse in diesen Fällen die Ungleichmässigkeit des Weizens verursacht hätten, sondern die Ursachen sind anderswo zu suchen. Kann es doch möglich sein, dass es sich um Erbfaktoren handelte. Sp.̈ter auszuführende Untersuchungen werden wohl die Frage lösen. In Finnland ist bei der Züchtungsarbeit von Getreidepflanzen überhaupt keine chemische Analyse angewandt worden. Vielleicht aber würden sich auf diesem Wege Weizen- und andere Getreidesorten mit höherem Proteingehalt entwickeln lassen. 